\title{
Phytochemical screening and antioxidant, analgesic, and anthelmintic effect of ethanolic extract of Merremia umbellate stems
}

Mst Nazmun Nahar ${ }^{1 \dagger}$, Amit Kumar Acharzo ${ }^{1 \dagger}$, Md Sohanur Rahaman ${ }^{1,2}$, Iffat Ara Zabeen ${ }^{1}$, Shariful Haque ${ }^{3,4}$ and Md Amirul Islam ${ }^{1 *}$ (D)

\begin{abstract}
Background: Merremia umbellata subsp. orientalis (Hallier f.), commonly known as Sapussunda in Bengali, is used in folk medicine for the treatment of different diseases such as helminthiasis, rheumatism, fever, wounds, burns, sores, management of pain due to cut etc. The present study was carried out to evaluate the antioxidant, analgesic and anthelmintic activities of ethanolic extract of stems of Merremia umbellate (ESMU).

Methods: Phytochemical investigation was carried by using standard chemical test as described in literatures. In vitro free radical scavenging activity of ethanolic extract was quantitatively estimated using DPPH (2,2-diphenyl-1picrylhydrazyl) free radicals scavenging assay. Total phenolic and tannin content were spectrophotometrically determined by Folin Ciocalteu reagent whereas the flavonoid was determined by aluminum chloride colorimetric assay. Acetic acid induced writhing method and hot plate method, using Swiss albino mice, were used to investigate the analgesic effect of ESMU whereas in-vitro anthelmintic activity was evaluated against Haemonchus contortus (Nematode) of cattle.

Results: Phytochemical screening revealed that the ESMU contain reducing sugar, alkaloids, flavonoids, tannins, gums, steroid, xanthoproteins, glycosides and acidic compound. In DPPH free radical scavenging assay, the extract showed scavenging potential with $\mathrm{IC}_{50}$ value of $161.81 \mu \mathrm{g} / \mathrm{mL}$. Total phenolics, tannin and flavonoid content of crude extract were found to be $87.4 \mathrm{mg} \mathrm{GAE} / \mathrm{gm}, 68.2 \mathrm{mg}$ GAE $/ \mathrm{gm}$ and $64.27 \mathrm{mg}$ QE/gm respectively. Significant $(P<0.001)$ analgesic effect was observed in acetic acid induced writhing method at both doses 250 and $500 \mathrm{mg} / \mathrm{kg}$. Similar effect was found in hot plate method that measures antinociceptive effect in response to heat stimuli. The ESMU also exhibited significant $(P<0.001)$ anthelmintic activity in a concentration dependent manner. The paralysis time and time for death were recorded as 9.30, 8.62 and 7.65 min and 19.58, 18.82, and 16.43 min respectively at a concentration of 25,50 and $100 \mathrm{mg} / \mathrm{mL}$ respectively.

(Continued on next page)
\end{abstract}

\footnotetext{
* Correspondence: maislam26@gmail.com

${ }^{\dagger}$ Mst. Nazmun Nahar and Amit Kumar Acharzo contributed equally to this work.

'Pharmacy Discipline, Life Science School, Khulna University, Khulna 9208,

Bangladesh

Full list of author information is available at the end of the article
}

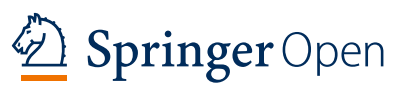

(c) The Author(s). 2020 Open Access This article is licensed under a Creative Commons Attribution 4.0 International License, which permits use, sharing, adaptation, distribution and reproduction in any medium or format, as long as you give appropriate credit to the original author(s) and the source, provide a link to the Creative Commons licence, and indicate if changes were made. The images or other third party material in this article are included in the article's Creative Commons licence, unless indicated otherwise in a credit line to the material. If material is not included in the article's Creative Commons licence and your intended use is not permitted by statutory regulation or exceeds the permitted use, you will need to obtain permission directly from the copyright holder. To view a copy of this licence, visit http://creativecommons.org/licenses/by/4.0/. 
(Continued from previous page)

Conclusion: Based on the results obtained in this study clearly strengthen the traditional uses of $M$. umbellate stems as antioxidant, antinociceptive and anthelmintic. Therefore, this result suggested that the stems of Merremia umbellata might be a potential source of useful bioactive compounds.

Keywords: Merremia umbellate, Antioxidant activity, Analgesic activity, Anthelmintic activity

\section{Introduction}

The family Convolvulaceae, known as morning glory family of flowering plants, consists of about 55 genera and 1600 species. They are widely distributed in tropical and sub-tropical regions across the world and cultivated for their colorful funnel-shaped flowers [1]. Plants of this family has prominent medicinal values such as Ipomoea batatas (Sweet potato or Misti Alu in bangla) used in the treatment of tumors of the mouth and throat, diabetes, bacterial infections, demulcent, fungal infection and so on [2]; Evolvulus alsinoides (known as Dwarf Morning), is used in the treatment of nervous debility, loss of memory, ulcer and syphilis [3]; Ipomoea aquatic, (known as Kalmisak in Bangladesh), is used in the treatment of fever, jaundice, biliousness, bronchitis, liver complaints, diabetic and high blood pressure [4]. Thus, plants of Convolvulaceae family would be an extensive alternative source of new drugs with characteristic chemical entities to combat the side effects of existing drugs used in the treatment of different diseases such as helminthiasis, diarrhea, disease related with oxidative stress such as cancer, diabetes, atherosclerosis, immunosuppression, swelling, cardio-vascular diseases and neurodegenerative disorders. Merremia umbellata (MU) is a member of Convolvulaceae family widely distributed throughout the tropical region of the world - Sri Lanka, India, Nepal, China, Bangladesh, Myanmar, Malaysia and Indonesia [5]. Merremia umbellate, commonly known as Sapussunda in Bangla, is a perennial vine with climbing stem and white flowers. Different parts of this plant have different traditional uses. Leaves are used as poultice on wounds, burns and sores [6,7], powder of leaves are used to treat epilepsy, roots are used as laxative [7], flowers are used to treat eye diseases, the whole plant is used as diuretic and in the treatment of rheumatism, headaches, paralyses, spasms, fever, convulsions [8-12].

The genus Merremia is a rich source of bioactive compounds. M. mammosa, for example, is reported to possess mammoside B, mammoside H1 [13]. Merremia tridentate is another member of this genus has been accounted for to have diosmetin, luteolin 7-O-beta-Dglucoside, luteolin and diosmetin 7-O-beta-D-glucoside [14]. The leaves of M. umbellata has anti-inflammatory, antioxidant, cytotoxic, antibacterial activity [15-17]. The whole plant, on the other hand possess eight phenolic compounds showed allelopathic effects on arabidopsis seed germination namely, SA 2-O- $\beta$-D-( $3^{\prime}, 6^{\prime}$-dicaffeoyl)glucopyranoside, rosmarinic acid, paprazine, N-P-ciscoumaroyltyramine, caffeic acid, esculetin, quercetin and luteolin [18]. It is evident from the existing information that this family of plants is rich sources of biologically active compounds, however, there are few scientific reports to evaluate the basis of traditional uses of $M$. umbellata. The present study, therefore, is intended to investigate the antioxidant, anthelmintic and analgesic activities of ethanolic extract of stem of $M$. umbellata (ESMU).

\section{Materials and methods Collection of plant materials}

The stems of Merremia umbellata were collected from healthy plants located at Khulna University campus. The experts of Bangladesh National Herbarium Center, Dhaka verified the collected plant parts and deposited voucher specimen (DACB 44943) for future reference.

\section{Preparation of extract}

The stems were separated from undesired plant debris after collection and carefully washed with distilled water. The collected plant parts were shade dried after cutting into small pieces and were ground into a fine powder with the help of a suitable grinder (Capacitor start motor, Wuhu Motor Factory, China). $250 \mathrm{~g}$ of powdered material was macerated with $700 \mathrm{~mL}$ of $95 \%$ ethanol in an airtight glass jar to prevent solvent evaporation at room temperature. The crude extract was filtered by using Whatman filter paper and condensed under reduced pressure using rotary evaporator at temperature of $40{ }^{\circ} \mathrm{C}$. The yield was found to be $1.8 \%$.

\section{Experimental rodent}

Swiss albino male mice (20-25 g) were brought from the International Centre for Diarrheal Disease and Research, Bangladesh (ICDDR, B). The animals were kept in animal house of pharmacy discipline of Khulna University under standard laboratory conditions (relative humidity $55-65 \%$, temperature $23.0 \pm 2.0^{\circ} \mathrm{C}$ and $12 \mathrm{~h}$ light-dark cycle for 7 days). The animals were fed standard pellet diet and water ad libitum carefully. 


\section{Chemicals and reagents}

The standard drug diclofenac sodium (analgesic) and albendazole (anthelmintic) were generous gift from Beximco Pharmaceuticals Limited, Dhaka, Bangladesh. On the other hand, Folin-Ciocalteu reagent, quercetin, 2, 2-diphenyl-1-picrylhydrazyl (DPPH), gallic acid, ascorbic acid and other chemicals as well as solvents were procured from Sigma Chemical Co. Ltd. (St. Louis, MO, USA). All reagents and solvents were of analytical grade.

\section{Phytochemical screening}

The preliminary phytochemical screening was qualitatively carried out by using specific standard methods $[19,20]$. Briefly, the presence of alkaloids were determined with Mayer's and Dragendroff's test, reducing sugars were detected with Fehling solution, flavonoids were detected with $\mathrm{NaOH}$, steroids were measured by Libermann-Burchard and sulphuric acid tests, tannins were estimated with Ferric chloride and Potassium dichromate test, glycosides were identified by Liebermann's test and $\mathrm{NaOH}$ solution, phenols were measured with ferric chloride test and Molisch test was used to test the presence of gums.

\section{Quantification of Total phenolic content}

The total phenolic content of the crude ethanolic extract was quantified by adopting the colorimetric FolinCiocalteu method [21, 22]. Briefly $0.5 \mathrm{~mL}$ extract solution $(1 \mathrm{mg} / \mathrm{mL})$ and standard gallic acid solution of different concentration range from $0.02 \mathrm{mg} / \mathrm{mL}$ to 0.15 $\mathrm{mg} / \mathrm{mL}$ in methanol were separately mixed with $5 \mathrm{~mL}$ $10 \%(\mathrm{v} / \mathrm{v})$ aqueous Folin-Ciocalteu reagent. Then an aliquot of $4 \mathrm{~mL}$ sodium carbonate solution $(7.5 \% \mathrm{w} / \mathrm{v})$ was added to the mixtures. The mixtures of different test tubes were then homogenized by vortex for $15 \mathrm{~s}$ and allowed to incubate at $40^{\circ} \mathrm{C}$ for $30 \mathrm{~min}$. Blank was also concomitantly prepared, containing all reagents except sample or standard. But without addition of sample or standard. The absorbance (optical density-OD) of each reaction mixtures were then measured using the spectrophotometer against blank at $765 \mathrm{~nm}$ wavelength. The absorbance of standard solution of different concentrations used to form the standard calibration curve from where total phenol content was determined expressed as mg gallic acid equivalent (GAE) per gram of dry extract.

\section{Quantification of Total flavonoid content}

The total flavonoid content of ESMU was estimated by following aluminum trichloride colorimetric method [23]. Briefly, one (1) $\mathrm{mL}$ of ethanolic solution of the extract $(1 \mathrm{mg} / \mathrm{mL})$ was mixed with $4 \mathrm{~mL}$ distilled water and $0.3 \mathrm{~mL}$ of $5 \%(\mathrm{w} / \mathrm{v})$ sodium nitrate solution. Five minutes after mixing, $0.3 \mathrm{~mL} 10 \%(\mathrm{w} / \mathrm{v})$ aluminum chloride was added to the mixture and further allowed to react for $1 \mathrm{~min}$. Then, $2 \mathrm{~mL}$ sodium hydroxide solution $(1 \mathrm{M})$ was added to the mixture, which was adjusted to $10 \mathrm{~mL}$ volume by adding distilled water. The mixture was then homogenized by shaking for $15 \mathrm{~s}$ and allowed to react for further $30 \mathrm{~min}$. Absorbance of the reaction mixture was measured at $510 \mathrm{~nm}$ against blank solution. Different concentrations $(0-1.0 \mathrm{mg} / \mathrm{mL})$ of quercetin were used to prepare the standard calibration curve from where total flavonoid content was determined and expressed as $\mathrm{mg}$ quercetin equivalent $(\mathrm{QE}) / \mathrm{g}$ of dried extract.

\section{Quantification of Total tannin content}

The tannins of crude ethanolic extract were quantified by following the Folin-Ciocalteu (FC) method [24, 25]. Briefly, $0.1 \mathrm{ml}$ ethanolic solution of gallic acid (a wellknown antioxidant) of each concentration (0.50, 0.40, $0.30,0.20,0.10 \mathrm{mg} / \mathrm{mL}$ ) and $0.1 \mathrm{ml}$ crude extract solution $(1 \mathrm{mg} / \mathrm{mL})$ was taken separately in different test tubes and diluted with $7.5 \mathrm{~mL}$ of distilled water. Then, $0.5 \mathrm{~mL}$ of $\mathrm{FC}$ reagent and $1 \mathrm{~mL}$ of $35 \% \mathrm{Na}_{2} \mathrm{CO}_{3}$ were added to each test tube subsequently and the total volume of mixture solution of each test tube was adjusted to $10 \mathrm{~mL}$ with distilled water. The blank solution that contain all above reagents except sample or standard was concomitantly prepared. The mixture of all test tubes was homogenized by shaking for $15 \mathrm{~s}$ and allowed to react for further $30 \mathrm{~min}$. The absorbance of each reaction mixtures was measured at $725 \mathrm{~nm}$ against blank solution. Total tannin content was expressed in terms of mg of GAE/g of the dry extract by using standard calibration curve of gallic acid.

\section{DPPH free radical scavenging assay (quantitative analysis} of antioxidant activity)

The free radical scavenging activity of ESMU was evaluated on the basis of its ability to scavenge DPPH free radical [26]. The crude extract and standard antioxidant, ascorbic acid were separately dissolved in methanol to get stock solution $(1024 \mu \mathrm{g} / \mathrm{mL})$ of both sample and standard. Then, the stock solutions of both were subjected to serial dilution to obtain solution of different concentration ranging from 512 to $1 \mu \mathrm{g} / \mathrm{mL}$. Afterwards, $6 \mathrm{~mL}$ of $0.004 \%$ solution of DPPH was added separately in different test tubes previously containing $2 \mathrm{~mL}$ aliquot of sample and standard solution of different concentration, each. The mixtures of all test tubes were homogenized by vigorous shaking for $15 \mathrm{~s}$ and allowed to incubate at room temperature for $30 \mathrm{~min}$ in dark to promote reaction of solution mixture. The absorbance of each solution mixture of both sample and standard was recorded using a UV spectrophotometer (Shimadzu UV1800, Japan) against a blank at $517 \mathrm{~nm}$. The experiment was repeated in duplicate manner and mean absorption 
was taken to calculate percentage of inhibition from following equation:

\%inhibition of DPPH $=\frac{\text { Blank OD }- \text { Sample OD or Standard OD }}{\text { Blank OD }} \times 100$

\section{Acute toxicity test}

The oral acute toxicity test was performed following the guidelines of the Organization for Economic Cooperation and Development [27]. The healthy mice of either sex were fasted overnight and divided into five groups $(n=5)$; four test groups were administered the extract at $100,200,400$ and $800 \mathrm{mg} / \mathrm{kg}$ of body weight orally and the control group received distilled water only. The individual animals were observed continuously for $2 \mathrm{~h}$ and 6 $\mathrm{h}$ intervals for $24 \mathrm{~h}$ and finally every $24 \mathrm{~h}$ for 14 days. The animals were monitored for physical signs of toxicity namely consumption of food and water, body weight disparity, writhing, urination, grasping, response to touch, varying muscular tone and locomotion and decreased respiratory rate or for any lethality.

\section{Evaluation of in vivo analgesic activity Acetic acid induced writhing test}

The in vivo analgesic activity of crude extract was evaluated by acetic acid induced writhing test model on mice $[28,29]$. The experimental laboratory mice were divided into four groups, 5 mice per group, named negative control group, positive control group and two test groups. The negative control group was administered $1 \%(\mathrm{v} / \mathrm{v})$ Tween- 80 at the dose of $10 \mathrm{~mL} / \mathrm{kg}$ body weight, the positive control group was given diclofenac sodium (reference drug) at the dose of $25 \mathrm{mg} / \mathrm{kg}$ body weight and the test groups were received the extract at the doses of 250 and $500 \mathrm{mg} / \mathrm{kg}$ body weight orally. Test samples, standard drug and control vehicle were administered orally $30 \mathrm{~min}$ before intraperitoneal administration of $0.7 \%$ of acetic acid. After an interval of $5 \mathrm{~min}$, the number of writhes for each group was counted for a period of 15 min. During counting, two subsequent incomplete writhings were counted as a full writhing. The percentile inhibition was calculated by following equation-.

\%Inhibition of writhing $=$

$\frac{\text { The mean writhing of control }- \text { The mean writhing of experimental group }}{\text { The mean writhing of control }} \times 100$

\section{Hot plate test}

The hot plate test is a rapid and relatively inexpensive method to evaluate acute, thermal pain. The analgesic effect of ESMU was evaluated by hot plate method described previously $[30,31]$ with slight modification. The experimental animals were divided into four groups; control group received only distilled water, the positive control received morphine at $10 \mathrm{mg} / \mathrm{kg}$ body weight and two test groups were administered the extract at dose of 250 and $500 \mathrm{~m} / \mathrm{kg}$ boy weight. The experimental animals were place into a perspex cylinder on the heated surface. The temperature of the heated surface was maintained at $55 \pm 2{ }^{\circ} \mathrm{C}$. The response time was recorded when mice licked their front and hind paws and jumped at before $(0 \mathrm{~min})$ and 30, 60, 90, 120, 180 and $240 \mathrm{~min}$ after oral administration of ESMU. The cut-off time was $20 \mathrm{~s}$.

\section{Evaluation of in vitro anthelmintic activity test}

The anthelmintic activity of ESMU was investigated on live parasites Haemonchus contortus (Nematode) of cattle [32]. In this test, the parasites were divided into negative control group, positive control group and three test groups consisted of six parasites respectively. The Petri dish served as negative control had $0.1 \%$ Tween 80 in phosphate buffered solution (PBS), petri dishes served as positive control had reference standard albendazole separately at the concentration of $15 \mathrm{mg} / \mathrm{mL}$ and petri dishes served as test group had crude extract separately at the concentrations of 25,50 and $100 \mathrm{mg} / \mathrm{mL}$ in PBS. Adult motile Haemonchus contortus were collected from the gastrointestinal tract of cattle slaughtered at local slaughterhouse and immediately transferred to that of different groups of petri dishes. The anthelmintic activity of extract was determined by measuring time required for paralysis $(\mathrm{P})$ and the time required for death $(\mathrm{D})$ of parasites in comparison with control. Time for paralysis (P) was noted when no movement of any sort could be observed except when the worms were vigorously shaken. On the other hand, the death time was recorded when worms lose their motility followed with fading away of their body color and did not revive even kept in only PBS.

\section{Statistical analysis}

Graph Pad prism version 5.0 (GraphPad software Inc., San Diego, CA) was used to perform one-way ANOVA followed by Dunnett post-hoc test statistical analysis in mice and helminths. Microsoft excel was used to perform statistical analysis of antioxidant experiment. All experimental values were expressed as mean \pm standard error of mean (SEM), $n=5$ (for analgesic activity), 6 (anthelmintic activity). Results were considered statistically significant when $P<0.05$ in all cases.

\section{Results}

\section{Phytochemical screening}

Preliminary phytochemical investigation showed the presence of various classes of Pharmacologically active constituents such as reducing sugar, alkaloids, flavonoids, tannins, gums, steroid, xanthoproteins and glycosides (Table 1). 
Table 1 Phytochemical constituents of ESMU

\begin{tabular}{llll}
\hline SI No. & Constituents & Test & Results \\
\hline 1 & Reducing sugar & Fehling's solution & + \\
2 & Alkaloids & Dragendorf's and Mayer's reagent & + \\
3 & Flavonoids & Sodium hydroxide & + \\
4 & Tannins & Ferric chloride and Potassium dichromate & + \\
5 & Steroids & Libermann-Burchard and sulphuric acid tests & + \\
6 & Glycosides & chloroform and 10\% ammonia solution & + \\
7 & Xanthoproteins & Conc. Nitric acid & - \\
9 & Gums & Molish's reagent & - \\
10 & Anthraquinone & Ammonia solution & + \\
\hline
\end{tabular}

${ }^{\prime}+{ }^{\prime}=$ presence, ${ }^{\prime \prime}=$ absence

\section{Quantification of Total phenolic content}

The total phenolic content of crude extract was estimated by using an equation, $\mathrm{y}=9.0907 \mathrm{x}+0.1724 ; R^{2}=$ 0.9812 , obtained from calibration curve of gallic acid (Fig. 1) and it was approximately found to be $57.1 \mathrm{mg}$ GAE in per gram of dry extract.

\section{Quantification of Total flavonoid content}

A standard calibration curve (Fig. 2) with the equation, $\mathrm{y}=0.515 \mathrm{x}-0.0011\left(R^{2}=0.9957\right)$ was obtained by plotting different concentrations of quercetin to calculate total flavonoid content of crude extract and it was found to be $65.12 \mathrm{mg} \mathrm{QE} / \mathrm{g}$ of dry extract.

\section{Quantification of Total tannin content}

The total tannin content of crude extract was estimated by using an equation, $\mathrm{y}=1.3765 \mathrm{x}-0.0103\left(R^{2}=0.9804\right)$ derived from a calibration curve of gallic acid (Fig. 3) and the value was found to be $57.1 \mathrm{mg} \mathrm{GAE} / \mathrm{g}$ of dry extract.

DPPH free radical scavenging assay (quantitative analysis of antioxidant activity)

The ESMU showed concentration dependent antioxidant activity with the $\mathrm{IC}_{50}$ value of $161.81 \mu \mathrm{g} / \mathrm{mL}$ against free radical of $\mathrm{DPPH}$ while the $\mathrm{IC}_{50}$ of ascorbic acid (a natural antioxidant) was found to be $14.99 \mu \mathrm{g} / \mathrm{mL}$ (Fig. 4).

\section{Evaluation of in vivo analgesic activity Acetic acid induced writhing test}

The crude stem extract showed significant $(P<0.001)$ inhibition of writhing reflex at the dose of $250 \mathrm{mg} / \mathrm{kg}$ and $500 \mathrm{mg} / \mathrm{kg}$ by $53.81 \pm 3.61 \%$ and $68.34 \pm 3.06 \%$ respectively, whereas standard, diclofenac sodium displayed inhibition of writhing reflex by $79.40 \pm 1.45 \%$ (Table 2 ).

\section{Hot plate test}

Figure 5 represents the summary of results of hot plate test. The treatment of mice with morphine $(10 \mathrm{mg} / \mathrm{kg}$ i.p.) increased the latency response in the hot plate test from 30 to $240 \mathrm{~min}$ after treatment. Significant prolongation of latency time was observed in both doses (250 mg/kg and $500 \mathrm{mg} / \mathrm{kg}$ of body weight) of ESMU. The effect begun early at $30 \mathrm{~min}$ after administration of ESMU and continues until the following fourth hour, which is comparable to the standard drug morphine.

\section{Evaluation of in vitro anthelmintic activity}

The crude extract at different concentration (25, 50 and $100 \mathrm{mg} / \mathrm{mL})$ exhibited significant $(P<0.001)$ anthelmintic activity in dose dependent manner. The extract at highest dose $100 \mathrm{mg} / \mathrm{mL}$ exhibited lowest time for paralysis $(7.65 \pm 0.09 \mathrm{~min})$ and for death $(16.43 \pm 0.40 \mathrm{~min})$ of Haemonchus contortus in comparison with standard drug, caused paralysis at $7.45 \pm 0.22 \mathrm{~min}$ and death at $15.83 \pm 0.47 \mathrm{~min}$ (Table 3 ).

\section{Discussion}

Plants synthesize and store secondary metabolites for their natural defense. These bioactive compounds have several live saving activities for these reason plants have been used as medicinal tool from ancient era [33, 34]. Phytochemical screening of ESMU in this study confirmed the presence of board spectrum bioactive metabolites (reducing sugar, alkaloids, flavonoids, tannins, gums, steroid, xanthoproteins, glycosides and acidic compound) that credited the plant as a potential medicinal entity.

Reactive oxygen species (ROS) are associated with numerous significant cellular activities such as gene transcription, signaling transduction, and immune response. Most frequent ROS incorporate hydroxyl radical $(\cdot \mathrm{OH})$, hydrogen peroxide $\left(\mathrm{H}_{2} \mathrm{O}_{2}\right)$ and superoxide $\left(\mathrm{O}_{2} \bullet-\right)$. These free radicals are produced in response to 


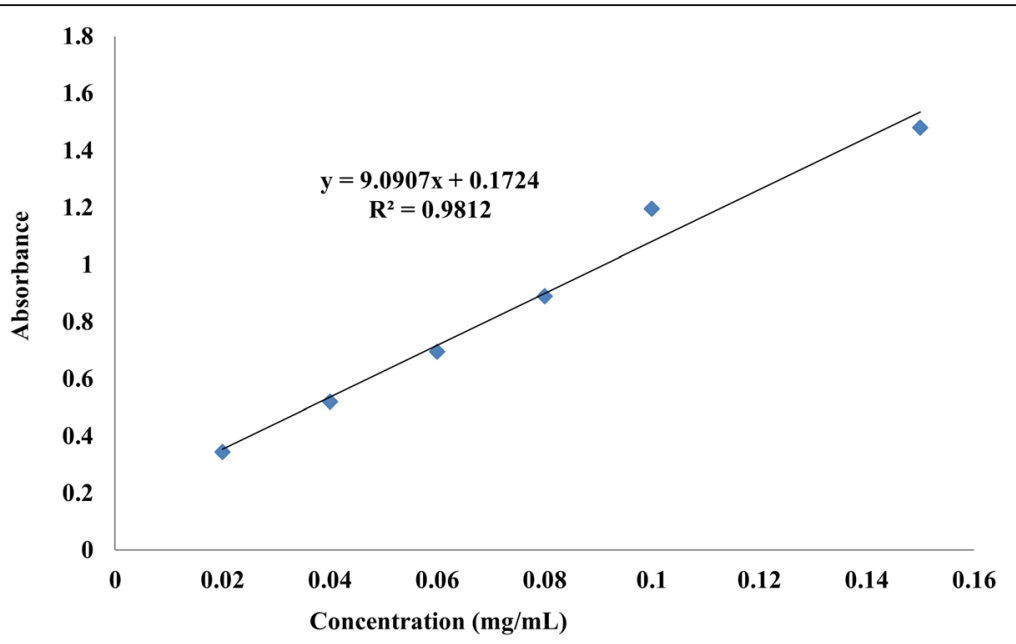

Fig. 1 Total phenolic content determination of Merremia umbellata extract with the help of gallic acid standard calibration curve

normal physiological process, however, overproduction of ROS can bring about oxidative harm to biomolecules, for example, lipids, proteins, and DNA, leading to various diseases including cancer, respiratory, inflammatory, cardiovascular, neurodegenerative, and digestive diseases. This oxidative stress (OS) eventually causes cellular death $[35,36]$. The harmful effect of OS can be neutralized by either cellular mechanisms or by intake of antioxidant from external sources. Thus, the antioxidant whether endogenous or externally supplied, can scavenge the ROS thereby reducing oxidation of biomolecules and restore the cellular activity [37].

The antioxidant activity of ESMU was carried out by measuring DPPH free radical scavenging capacity and quantitative measurement of antioxidant compounds phenol, flavonoid and tannin contents of the extract.
The DPPH is visible deep violet in color due to the delocalization of the spare electron over the molecule and that can be characterized by an absorption band at about $517 \mathrm{~nm}$ [38]. An antioxidant compound can decolorize the visible deep violet color of DPPH either by supplying hydrogen atoms or electron and that can quantitatively be measured from the change in the absorbance, which is inversely proportional to respective concentration $[38,39]$. Thus, the gradual increasing of concentration of both crude extracts and ascorbic acid caused gradual decreasing in absorbance of solution mixture advocated the antioxidant activity of crude extract. (Fig. 4). Phenolic compounds such as tannins and flavonoids are important for antioxidant activity in many plants because of their hydrogen donating property to neutralize free radicals [25]. Since, both the quantity and

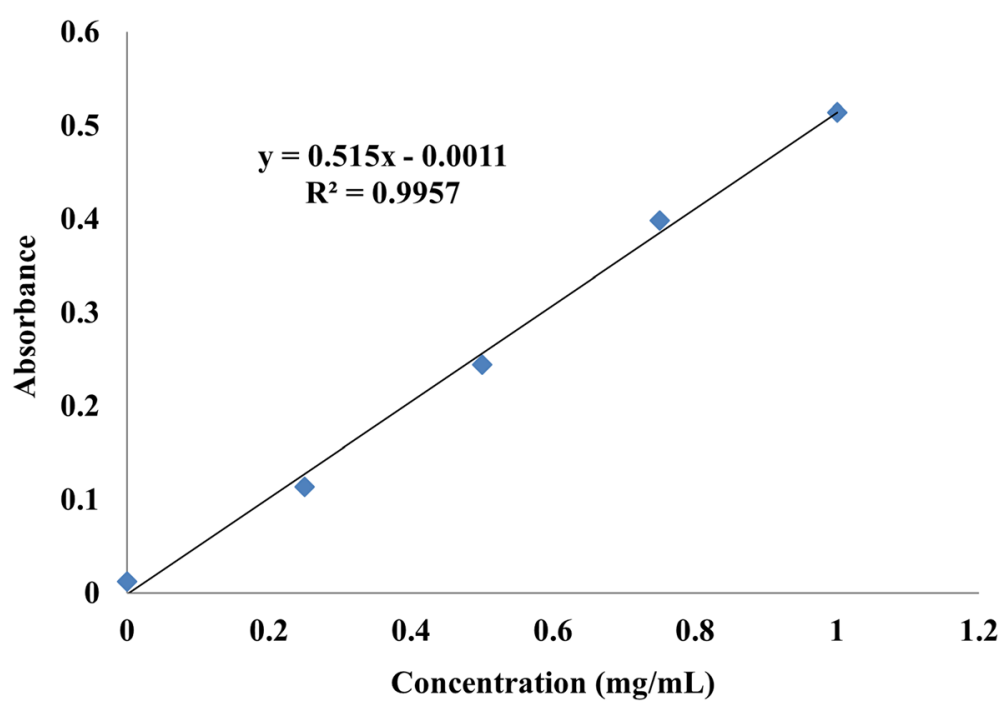

Fig. 2 Total flavonoid content determination of Merremia umbellata extract with the help of Quercetin standard calibration curve 


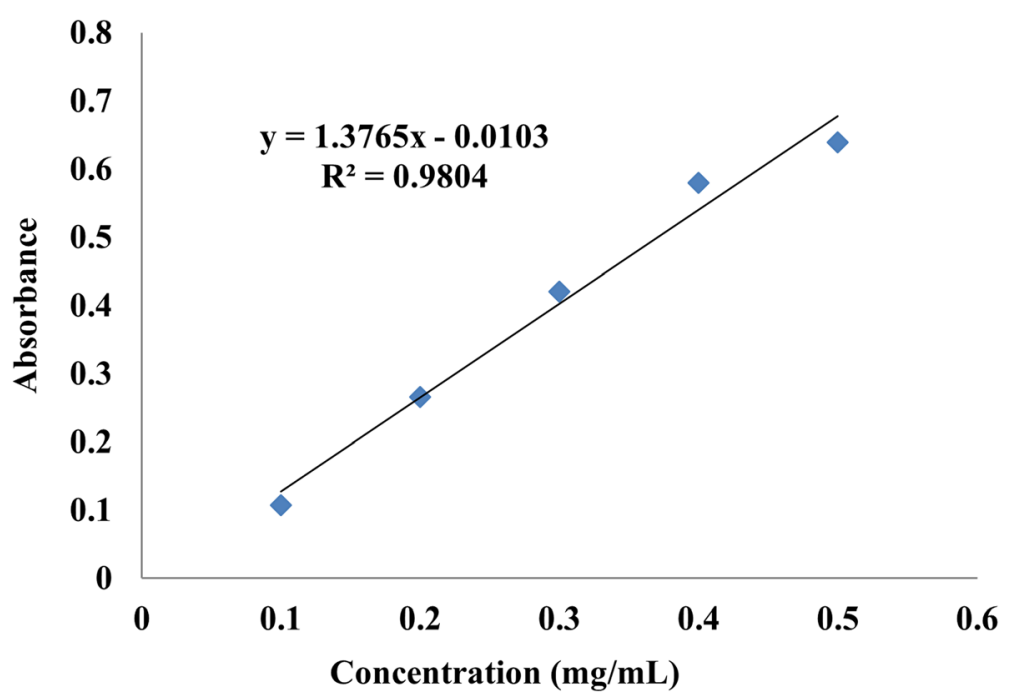

Fig. 3 Total tannin content determination of Merremia umbellata extract with the help of gallic acid standard calibration curve

type of polyphenols characterize the antioxidant activity of plant extract; we herein also quantified the total phenolic contents, total flavonoid contents, and total tannin contents. Total phenol contents, flavonoids contents and tannin contents results obtained in this study revealed that the quantity of these compounds in the crude extract were apparently lower, thus led lower antioxidant activity. On the other hand, though the whole plant Merremia umbellate reported with prominent antioxidant compounds- quercetin, luteolin, rosmarinic acid, caffeic acid, esculetin, the crude extract revealed antioxidant activity presumably due to either their presence in the stem part of this plant in small amount or in complex form [18].
Currently available analgesic drugs are not be used in all cases because of having several side effects, so new analgesic drug with better pain management capacity and with lowest side effect are being called for with urgency. So, the analgesic activity of the crude extract was evaluated by acetic acid induced writhing in mice model. This protocol is widely believed to investigate peripheral analgesic activity of crude extract [40, 41]. The intraperitoneal administration of acetic acid causes pain in mice through physiological stimuli which provokes cyclooxygenase pathway to synthesize increased level of local endogenous substances, such as prostaglandin $E_{2}$ and $F_{2 \alpha}$ as well as lipoxygenase pathway to synthesize increased level of eicosanoids in the peritoneal fluid that

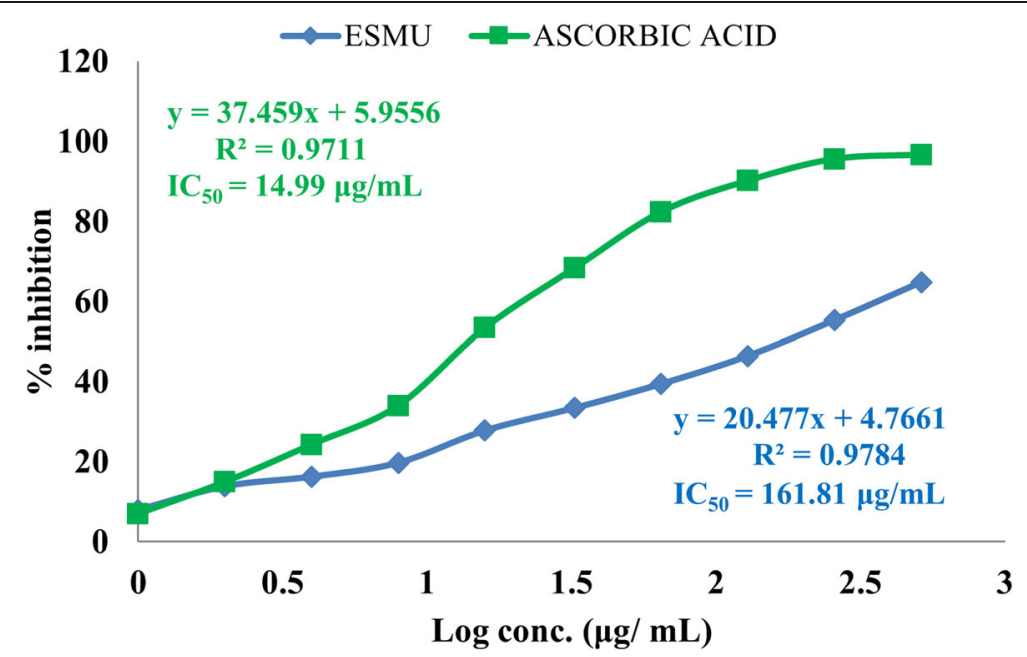

Fig. 4 DPPH scavenging activity of stem extract of Merremia umbellata 
Table 2 Effect of ethanolic extract of M. umbellata on acetic acid-induced writhing in mice

\begin{tabular}{llll}
\hline Treatment $(\boldsymbol{n}=\mathbf{5})$ & Dose $\mathbf{( m g / k g )}$ & No. of writhes & \% Writhing inhibition \\
\hline Control & $1 \%$ Tween-80 in water & $36 \pm 0.71$ & $79.40 \pm 1.45$ \\
Standard & 25 & $7.4 \pm 0.51^{*}$ & $53.81 \pm 3.61$ \\
Extract & 250 & $16.60 \pm 1.08^{*}$ & $68.34 \pm 3.06$ \\
& 500 & $11.40 \pm 0.93^{*}$ & \\
\hline
\end{tabular}

Values are expressed as mean \pm SEM, SEM: Standard error for mean, $\mathrm{n}$ : Number of mice $(5),{ }^{*} P<0.001$ compared to control

stimulate nociceptive neurons which has been reported to be responsible for pain sensation. Writhing is an obvious response of pain via nociceptors characterized by the recurrence of extension of hind limbs and contraction of abdominal musculature for a prolonged period of time and thought to be mediated by peritoneal mast cells and sensing ion channels and prostaglandin pathways [42, 43]. Results of present study suggest that ESMU displayed significant $(P<0.001)$ writhing inhibition through interfering peripheral mechanism of pain inhibition [44]. On the other hand, it has been reported that the precursor of pain inducing endogenous substances, arachidonic acid derived from inflammatory tissue damage is the consequence of reactive oxygen species from phagocytes that invading into the inflammation site [45]. Thus, the antioxidant activity of plant extract also advocated the analgesic activity of plant extract. So, analgesic and antioxidant activities could be correlated in pain management $[46,47]$. Plant materials containing phenolic compounds such as flavonoids (a powerful antioxidant) exert reportedly analgesic activity primarily via targeting prostaglandins [48]. Additionally, the alkaloids, already been documented its existence upon phytochemical screening in this study, is also responsible for showing analgesic effect. Since this test is sensitive to non-steroidal anti-inflammatory drugs, alkaloid might exert analgesic effect by inhibition of lipooxygenase and/or cyclo-oxygenase pathway or by release of cytokines such as TNF- $\alpha$, interleukin- $1 \beta$ and interleukin- 8 by resident peritoneal macrophages and mast cells $[40,49,50]$.

The response of experimental mice to thermal stimuli measured by hot plate test is a validated model for the detection of opiate analgesic [51,52]. Although the nociceptive response started at $30 \mathrm{~min}$ of the experiment, the highest response was significantly observed at $90 \mathrm{~min}$ in both doses. The response time was found to be increased from 6.2 to $13.5 \mathrm{~s}$ for extract that was comparable to that of standard drug morphine where the highest response time was $16.33 \mathrm{~s}$ at $90 \mathrm{~min}$ of study. The significant increase of the latency time in hot plate method indicates that the extracts exhibited antiociceptive effect by centrally acting. Together with the results of acetic acid-induced writhing method, we could say that the extract showed its analgesic effect by both central and peripheral mechanism.

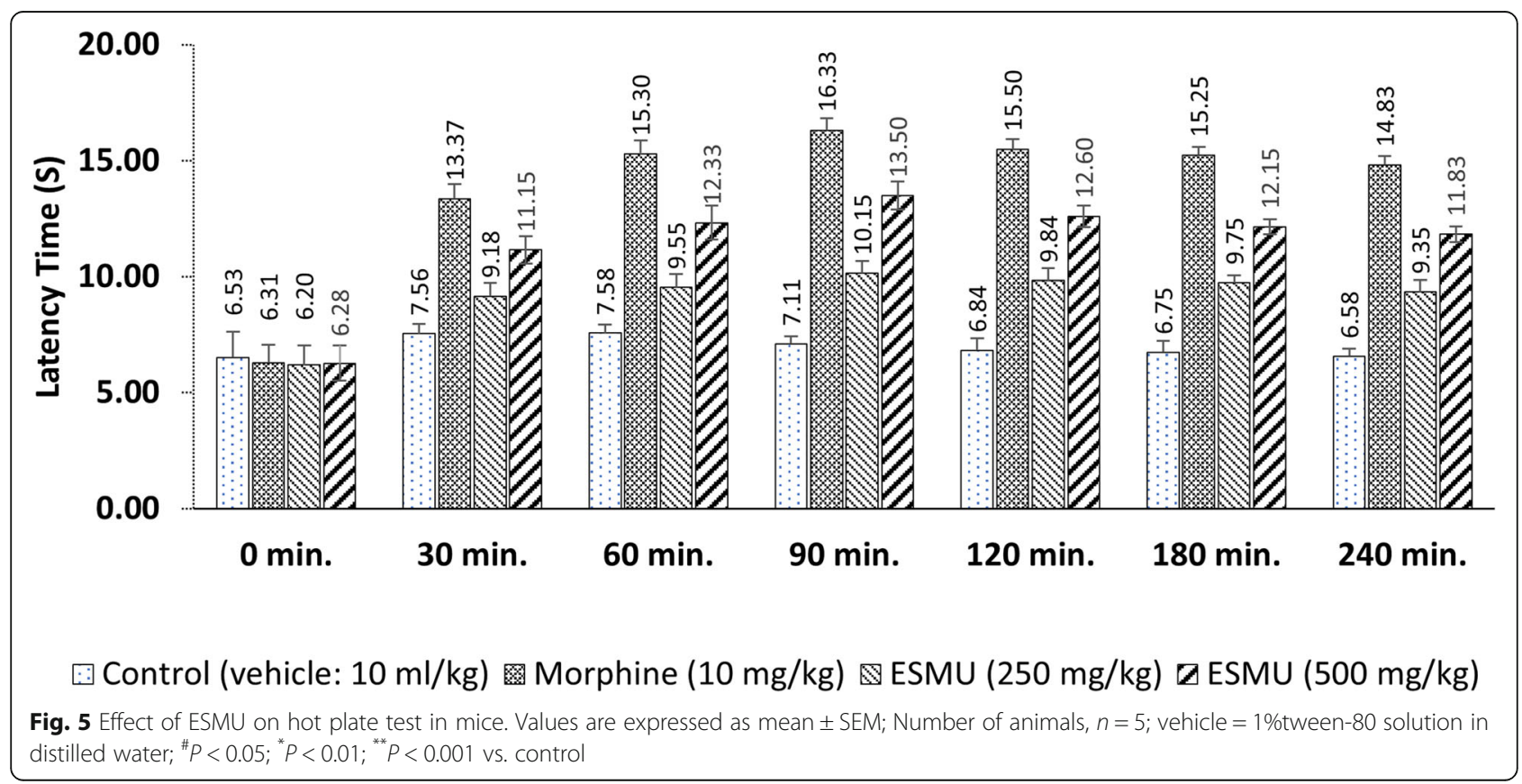


Table 3 Effect of ethanolic extract of M. umbellata on Haemonchus contortus

\begin{tabular}{llll}
\hline $\begin{array}{l}\text { Treatment } \\
(\boldsymbol{n}=6)\end{array}$ & Conc. $(\mathrm{mg} / \mathrm{mL})$ & \multicolumn{2}{l}{ Time $(\mathrm{min})$ taken for paralysis (P) and death (D) } \\
\cline { 3 - 4 } & & $\frac{\text { Haemonchus contortus }}{\mathbf{P}}$ & $\mathbf{D}$ \\
\hline Control & $0.1 \%$ Tween 80 in PBS & $15.83 \pm 0.47^{*}$ \\
Standard & 15 & $7.45 \pm 0.22^{*}$ & $19.58 \pm 0.24^{*}$ \\
Extract & 25 & $9.30 \pm 0.12^{*}$ & $18.82 \pm 0.22^{*}$ \\
& 50 & $8.62 \pm 0.11^{*}$ & $16.43 \pm 0.40^{*}$ \\
\hline
\end{tabular}

Values are expressed as mean \pm SEM, SEM: Standard error for mean, $\mathrm{n}$ : Number of parasites $(6),{ }^{*} P<0.001$ compared to control

The use of natural products as anthelmintics has got great attention due to emergence of resistant strains, presence of drug residue in animal products and toxicity of synthetic drugs [53]. The in-vitro anthelmintic activity of ESMU was carried out against live parasites Haemonchus contortus (Nematode), where albendazole was used as reference drug. The results showed the crude extract and standard displayed similar effect in comparison with negative control (0.1\% Tween 80 in PBS). The extract at concentration 25,50 and $100 \mathrm{mg} / \mathrm{mL}$ displayed significant $(P<0.001)$ activity for paralysis time and death time. Thus, the obtained result apprises the local use of the stem of MU as anthelmintic. Phytoconstituents like alkaloids, tannins determined in this study, have been reported significant anthelmintic activity [54]. Tannins, a polyphenolic compound, may exert its anthelmintic activity either by binding with free proteins in the gastro intestinal tract of host animal or interfering with energy generation mechanism of worms through uncoupling oxidative phosphorylation or binding with glycoprotein on the cuticle of the parasite and cause death of worms $[54,55]$. On the other hand, alkaloid may exert its anthelmintic activity either by acting on its central nervous system or by affecting the permeability of the cell membrane of worms or both mechanisms [54]. Though the whole plant MU has been reported with prominent anthelmintic compound fortified with antioxidant activity- luteolin [18], the crude extracts' lowest antioxidant activity led to speculate that the crude extract of stem part might either possesses luteolin in complex form or possesses in minute amount or possesses other anthelmintic compound(s). Therefore, further phytochemical, biochemical as well as histopathological investigations are needed to identify the active principle (s) and establish the mechanism of action (s) to support the traditional use of this plant part.

\section{Conclusion}

It could be concluded that the stem extract of M. umbellata provides convincing evidence of beneficial health effects. The ethanolic extract of stem of M. umbellata was found to have moderate levels of phenolic, flavonoids and tannin content proving to have analgesic activity. The secondary bioactive metabolites identified in ESMU found to be biologically active in term of good analgesic ability and powerful anthelmintic activity. These results could scientifically justify the use of stem of $M$. umbellata in traditional medicine in the treatment of helminthiasis and algesia.

\section{Abbreviations}

ESMU: Ethanolic extract of stems of Merremia umbellate; DPPH: 2,2-diphenyl1-picryldydrazyl; GAE: Gallic Acid Equivalent; $I_{50}: 50 \%$ Inhibitory

Concentration; OD: Optical Density; $R^{2}$ : Coefficient of Determination

\section{Acknowledgements}

We are thankful to Pharmacy Discipline, Khulna University, Bangladesh for providing the facilities to perform the study. We are also grateful to Beximco Pharmaceuticals Limited, Dhaka, Bangladesh for providing diclofenac sodium and albendazole. We also extend our gratitude to International Centre for Diarrheal Disease and Research, Bangladesh (ICDDR, B) for supplying the experimental mice.

\section{Authors' contributions}

MNN and AKA were involved in collection of plant parts, laboratory experiments, data acquisition, interpretation of results and report writing. MSR, IAZ and SH did critical statistical analysis and experiments. Concept development, experiment design, overall monitoring and final approval of the manuscript was done by MAI.

\section{Funding}

Not applicable.

\section{Availability of data and materials}

The datasets supporting the conclusions of this article are included within the article.

\section{Ethics approval}

The study was approved by the Animal Ethics Committee of Khulna University, Bangladesh (Research Ref. no.: KUAEC-2019/11/13).

Consent for publication

Not applicable.

\section{Competing interests}

The authors declare that they have no conflict of interest.

\section{Author details}

${ }^{1}$ Pharmacy Discipline, Life Science School, Khulna University, Khulna 9208, Bangladesh. ${ }^{2}$ Department of Regenerative Medicine, College of Medicine, Soonchunhyang University, Cheonan 31151, Republic of Korea. ${ }^{3}$ Department of Pharmacy, Pabna University of Science and Technology, Rajapur, Pabna 6600 , Bangladesh. ${ }^{4}$ Graduate School of Life Science, Hokkaido University, Sapporo, Japan. 
Received: 6 May 2020 Accepted: 23 November 2020 Published online: 07 December 2020

\section{References}

1. Sultana R, Rahman AH. Convolvulaceae: a taxonomically and medicinally important morning glory family. Int J Botany Stud. 2016;1:47-52.

2. Meira M, Silva EP, David JM, David JP. Review of the genus Ipomoea: traditional uses, chemistry and biological activities. Rev Bras. 2012;22: 682-713.

3. Singh A. Review of Ethnomedicinal uses and pharmacology of Evolvulus alsinoides Linn. Ethnobot Leaf. 2008;12:734-40.

4. Manvar MN, Desai TR. Phytochemical and pharmacological profile of Ipomoea aquatica. Indian J Med Sci. 2013;67:49-60.

5. Simões AR, Silva $H$, Silveira $P$. The Convolvulaceae of Timor with special reference to East Timor. Blumea-Biodiversity, Evol Bio Plants. 2011;56:49-72.

6. Van Ooststroom SJ, Hoogland RD. Convolvulaceae. Flora Malesiana. 1953;4: 439-54.

7. Quattrocchi U. CRC world dictionary of medicinal and poisonous plants: common names, scientific names, eponyms, synonyms, and etymology (5 volume set): CRC press; 2012.

8. Burkill HM. The Flora of west tropical Africa. Kew: Royal Botanic Gardens; 1985

9. DeFilipps RA, Maina SL, Pray LA. The Palauan and Yap medicinal plant studies of Masayoshi Okabe, 1941-1943. Atoll Res Bull:1988.

10. Flowers of India. Merremia umbellata. http://www.flowersofindia.net/catalog/ slides/Yellow\%20Hogvine.html. Accessed 25 October 2019.

11. Rahmatullah M, Khatun Z, Saha S, Tuly MA, Hossain A, Roy A, Jahan R. Medicinal plants and formulations of tribal healers of the Chekla clan of the Patro tribe of Bangladesh. J Altern Complement Med. 2014;20:3-11.

12. Dutta ML. Plants used as ethnomedicine by the Thengal Kacharies of Assam, India. Asian J Plant Sci Res. 2017;7:7-8.

13. Krishnappan AL, Seetharaman TR. Flavonoids of Merremia tridentate. Fitoterapia. 1992;63:190.

14. Kitagawa I, Baek NI, Ohashi KO, Sakagami M, Yoshikawa M, Shibuya H. Mammoside $\mathrm{B}$ and $\mathrm{H} 1$, new ionophoric resin-glycoside from the tuber of Merremia mammosa, an Indonesian folk medicine. Chem Pharm Bull. 1989; 37(4):1131-3.

15. Castro Guerrero JP, Ocampo Buendía YC, Franco Ospina LA. Actividad antiinflamatory antioxidante de Merremia umbellata (L.) Hallier f, vol. 4; 2013. p. 13-9.

16. Ganjir M, Behera DR, Bhatnagar S. Phytochemical analysis, cytotoxic and antioxidant potential of Ipomoea pes caprae (L) R. Br and Merremia umbellata (L.) H. Hallier. Int J Sci Technol Res. 2013;2:80-3.

17. Rivera DE, Ocampo YC, Castro JP, Caro D, Franco LA. Antibacterial activity of Physalis angulata L., Merremia umbellata L., and Cryptostegia grandiflora Roxb. Ex R. Br.-medicinal plants of the Colombian northern coast. Orient. Pharm. Exp. Med. 2015;15:95-102

18. Yan J, Bi HH, Liu YZ, Zhang M, Zhou ZY, Tan JW. Phenolic compounds from Merremia umbellata subsp orientalis and their allelopathic effects on Arabidopsis seed germination. Molecules. 2010;15:8241-50.

19. Ghani A. Medicinal plants of Bangladesh. In: The Asiatic Society of Bangladesh. 2nd ed; 2003. p. 228-9.

20. Evans WC. Trease and Evan's textbook of Pharmacognosy, 13th ed, p 546. London: Cambridge University Press; 1989.

21. Biswas NN, Saha S, Ali MK. Antioxidant, antimicrobial, cytotoxic and analgesic activities of ethanolic extract of Mentha arvensis L. Asian Pac J Trop Biomed. 2014:4:792-7.

22. Hossain H. Moniruzzaman Sk, Nimmi I, Kawsar H, Hossain a, Islam a, Jahan IA. Anti inflammatory and antioxidant activities of the ethanolic extract of Ceriops decandra (Griff.) ding Hou bark. Orient Pharm Exp Med. 2011:11:215-20

23. Wolfe K, Wu X, Liu RH. Antioxidant activity of apple peels. J Agric Food Chem. 2003:51:609-14.

24. Zilani MNH, Islam MA, Khushi SS, Shilpi JA, Rahman MM, Hossain MG. Analgesic and antioxidant activities of Colocasia fallax. Orient Pharm Exp Med. 2016;16:131-7.

25. Tamilselvi N, Krishnamoorthy P, Dhamotharan R, Arumugam P, Sagadevan E. Analysis of total phenols, total tannins and screening of phytocomponents in Indigofera aspalathoides (Shivanar Vembu) Vahl EX DC. J Chem Pharm. 2012;4:3259-62
26. Blois MS. Antioxidant determinations by the use of a stable free radical. Nature. 1958:181:1199-200.

27. Kitano M. Updating of OECD guidelines for the testing of chemicals. Water Sci Technol. 1992;26(12):465-72.

28. Islam MA, Ahmed F, Das AK, Bachar SC. Analgesic and anti-inflammatory activity of Leonurus sibiricus. Fitoterapia. 2005;76:359-62.

29. Whittle BA. The use of changes in apillary permiability in mice to distinguish between narcotic and nonnarcotic analgesics. Br J Pharmacol Chemother. 1964;22:246.

30. Franzotti EM, Santos CVF, Rodrigues HMSL, Mourao RHV, Andrade MR, Antoniolli AR. Anti-inflammatory, analgesic activity and acute toxicity of Sida cordifolia L. (Malva branca). J Ethnopharmacol. 2000;72:273-8.

31. Woolfe G, MacDonald AD. The evaluation of the analgesic action of pethidine hydrochloride (Demerol). J Pharmacol Exp Ther. 1944;80:300-30.

32. Ferreira LE, Castro PMN, Chagas ACS, França SC, Beleboni RO. In vitro anthelmintic activity of aqueous leaf extract of Annona muricata $L$. (Annonaceae) against Haemonchus contortus from sheep. Exp Parasitol. 2013;134(3):327-32.

33. Michael W. Introduction: Biochemistry, Physiology and Ecological Functions of Secondary Metabolites. In: Annual Plant Reviews Volume 40: Biochemistry of Plant Secondary Metabolism, Second Edition; 2010. p. 1-19.

34. Thomas H. From waste products to ecochemicals: fifty years research of plant secondary metabolism. Phytochem. 2007:68:2831-46.

35. Rogers NM, Seeger F, Garcin ED, Roberts DD, Isenberg JS. Regulation of soluble guanylate cyclase by matricellular thrombospondins: implications for blood flow. Front Physiol. 2014;5:134. https:/doi.org/10.3389/fphys.2014.00134.

36. Zuo L, Zhou T, Pannell BK, Ziegler AC, Best TM. Biological and physiological role of reactive oxygen species-the good, the bad and the ugly. Acta Physiol. 2015;214:329-48. https://doi.org/10.1111/apha.12515.

37. Gilgun-Sherki Y, Melamed E, Offen D. Oxidative stress inducedneurodegenerative diseases: the need for antioxidants that penetrate the blood brain barrier. Neuropharm. 2001:40:959-75. https://doi.org/10.1016/ S0028-3908(01)00019-3.

38. Alam MN, Bristi NJ, Rafiquzzaman M. Review on in vivo and in vitro methods evaluation of antioxidant activity. Saudi Pharm J. 2013;21:143-52.

39. Rahman S, Sarder M, Shilpi JA, Hasan CM. Antioxidant and analgesic activity of Clerodendrum visconsum leaf. Orient Pharm Exp Med. 2006;6(4):319-23.

40. Gené RM, Segura L, Adzet T, Marin E, Iglesias J. Heterotheca inuloides: antiinflammatory and analgesic effect. J Ethnopharmacol. 1998;60:157-62.

41. Roberts LI. Analgesic-antipyretic and anti-inflammatory agents and drugs employed in the treatment of gout. In: Goodman and Gilman's the pharmacological basis of therapeutics; 2001.

42. Gawade S. Acetic acid induced painful endogenous infliction in writhing test on mice. J Pharmacol Pharmacother. 2012;3:348.

43. Kumar D. Anti-inflammatory, analgesic, and antioxidant activities of methanolic wood extract of Pterocarpus santalinus L. J Pharmacol Pharmacother. 2011:2:200-2.

44. Muhammad N. In-vivo models for management of pain. J Pharm Pharmacol. 2014:5:92.

45. Parke DV, Sapota A. Chemical toxicity and reactive oxygen species. Int J Occup Med Environ Health. 1996;9(4):331-40.

46. Gülçin I, Küfrevioǧlu Öi, Oktay M, Büyükokuroǧlu ME. Antioxidant, antimicrobial, antiulcer and analgesic activities of nettle (Urtica dioica L.). J Ethnopharmacol. 2004;90:205-15.

47. Areekul V, Phomkaivon N. Thai indigenous plants: focusing on Total phenolic content, antioxidant activity and their correlation on medicinal effects. KMITL Sci Tech J. 2015;15:10-23.

48. Karmakar UK, Rahman KS, Biswas NN, Islam MA, Ahmed MI, Shill MC, Paul P, Kamruzzaman M. Antidiarrheal, analgesic and antioxidant activities of Trapa bispinosa Roxb. Fruits. Res J Pharm Tech. 2011;4:294-7.

49. Vane JR, Botting RM. The mechanism of action of aspirin. Thromb Res. 2003 $110 \cdot 255-8$.

50. Ribeiro RA, Vale ML, Thomazzi SM, Paschoalato AB, Poole S, Ferreira SH, Cunha FQ. Involvement of resident macrophages and mast cells in the writhing nociceptive response induced by zymosan and acetic acid in mice. Eur J Pharmacol. 2000;387(1):111-8.

51. Sewell RDE, Spencer PSJ. Antinociceptive activity of narcotic agonist and partial agonist analgesics and other agents in the tail-immersion test in mice and rats. Neuropharmacol. 1976;15:23-9.

52. Adzu B, Amos S, Kapu SD, Gamaniel KS. Anti-inflammatory and anti-nociceptive effects of Sphaeranthus senegalensis. J Ethnopharmacol. 2003;84:169-73. 
53. Asase A, Oteng-Yeboah AA, Odamtten GT, Simmonds MS. Ethnobotanical study of some Ghanaian antimalarial plants. J Ethnopharmacol. 2005;99(2): 273-9.

54. Manke MB, Raut JS, Dhawale SC, Karuppayil SM. Antifungal activity of Helicteres isora Linn. Fruit extracts against planktonic and biofilm growth of Candida albicans. J Biol Act Prod Nat. 2015;55:357-64.

55. Thompson DP, Geary TG. The structure and function of helminth surfaces. In: InBiochemistry and molecular biology of parasites: Academic Press; 1995. p. 203-32.

\section{Publisher's Note}

Springer Nature remains neutral with regard to jurisdictional claims in published maps and institutional affiliations.

\section{Submit your manuscript to a SpringerOpen ${ }^{\circ}$ journal and benefit from:}

- Convenient online submission

Rigorous peer review

- Open access: articles freely available online

High visibility within the field

- Retaining the copyright to your article

Submit your next manuscript at $\boldsymbol{\wedge}$ springeropen.com 